\title{
PLACENTAL POLYP: A CASE STUDY
}

Ravindra Shelmohakar' ${ }^{1}$ Mithi Sooknundun ${ }^{2}$

\section{HOW TO CITE THIS ARTICLE:}

Ravindra Shelmohakar, Mithi Sooknundun. "Placental Polyp: A Case Study". Journal of Evolution of Medical and Dental Sciences 2014; Vol. 3, Issue 28, July 14; Page: 7768-7770, DOI: 10.14260/jemds/2014/2969

ABSTRACT: A placental polyp is an intrauterine, polypoid or pedunculated mass of placental tissue retained after an incomplete abortion or term pregnancy. The case report shows a large polyp arising from fundus anteriorly in a 22 years old female, primigravida with 22 weeks who aborted 2 months back and since than has been bleeding. In our study, the diagnostic and operative hysteroscopy confirmed to be ideal for this case study.

KEYWORDS: Placental polyp, Polypoid, Primigravida, Hysteroscopy.

INTRODUCTION: Hemorrhage after abortion is rare, occurring in less than $1 \%$ of abortions, but associated morbidity may be significant. Minimal bleeding after an abortion is normal up to a week and women usually get back to routine activities within a day or two. If bleeding hasn't stopped after 14 days and there is severe abdominal pain, the situation may be alarming.(1) Hemorrhage after surgical abortion is more common in the $2^{\text {nd }}$ trimester than in the $1^{\text {st }}$ trimester, estimates ranging from 0.9 to $10 \%$ per 1000 cases. Hemorrhage can be caused by atony, coagulopathy and abnormal placentation, as well as by such procedure complications as perforation, cervical laceration and retained tissue.(1)

Causes of Post abortion Hemorrhage and Associated Risk Factors (2)

\begin{tabular}{|l|l|}
\hline Causes of Hemorrhage & \multicolumn{1}{c|}{ Risk factors } \\
\hline Atony & $\begin{array}{l}\text { Prior CS, use of halogenated anesthetic agents, } \\
\text { gestational age more than 20 weeks and } \\
\text { increasing maternal age. }\end{array}$ \\
\hline Cervical laceration & $\begin{array}{l}\text { Surgical inexperience, incomplete cervical dilatation, } \\
\text { nulliparity and gestational age more than 20 weeks. }\end{array}$ \\
\hline Perforation & $\begin{array}{l}\text { Surgical inexperience, incomplete cervical } \\
\text { dilatation, increased gestational age, non-use of } \\
\text { intra-operative ultrasound }\end{array}$ \\
\hline Abnormal placentation & Uterine scar \\
\hline Coagulopathy & Personal or family history of bleeding. \\
\hline Retained tissue & Intraoperative ultrasound and surgical inexperience. \\
\hline
\end{tabular}

While retained tissue can lead to hemorrhage, most studies examine the association of retained tissue with re-aspiration, not hemorrhage. Because re-aspiration may be done for pain concerning for hematometra, these studies likely over estimate hemorrhage incidence. Re-aspiration is rare, occurring in $0.2-2 \%$ of first-trimester abortions. In the second trimester, a suction procedure is more common after medical abortion than surgical abortion, usually for retained placenta and not hemorrhage. Provider inexperience has been associated with retained tissue.(2) Due to delicacy of the condition, a multidisciplinary approach is needed.(3) In diagnostics, beside pelvic examination and 
ultrasound, hysteroscopy is usually preferred, although much more sophisticated and expensive procedures have been described in literature from our knowledge.(3)

CASE REPORT: A 22years old female, nullipara A1, admitted at Sterling hospital Nigdi, Pune complaining of per vaginal bleeding since 2 months, pain in abdomen, low grade fever and generalized weakness since 8 days. She gave history of spontaneous abortion 2 months back at 22 weeks of gestation. On examination, patient's vitals were stable, P/A: tenderness was present supra pubically, $\mathrm{P} / \mathrm{S}$ : bleeding was present and on $\mathrm{P} / \mathrm{V}$ : uterus was bulky with $\mathrm{B} / \mathrm{L}$ fornices free, non tender. Patient had consulted a doctor outside who advised USG, which showed signs of choriocarcinoma. She was given Methotrexate but there wasn't any improvement. A repeat USG was done and again which gave the same earlier findings. CT scan of Pelvis revealed well defined $3.7 \times 2.5 \mathrm{cms}$ sized heterogeneous lesion in endometrial cavity and encroaching the anterior wall. MRI Pelvis showed ill defined heterogenous lesion in the inner myometrium of the anterior uterine wall near the fundus. It measures 3.0(SI)x 1.9(AP)x 2.6(RL) cms. HCG levels shows level less than $1.20 \mathrm{mIU} / \mathrm{ml}$. Decision was made to perform Dilatation and Curettage with Hysteroscopy. Dilatation \& Curettage was performed and specimen sent for HPE and suggested? Endometrial secretory tissue and? necrotic tissue. Hysteroscopy revealed an ill-defined heterogeneous lesion on anterior uterine wall suggestive of? placenta accreta/? retained products of conception. The procedure was completed soundly and no bleeding or any other intraoperative complication occurred. The patient had minimal bleeding after OT and completely stopped bleeding after 4 days.

\section{DISCUSSION AND CONCLUSION:}

1. In women with a uterine scar and a placenta previa at 16 or more weeks' gestation, an evaluation for placenta accreta is strongly recommended. If a formal radiologic evaluation cannot be done, a provider experienced in ultrasound should evaluate for placenta accreta. Ultrasound is recommended as a first step in evaluating for placenta accreta. If the diagnosis is uncertain, MRI should be considered.(4)

2. Bleeding is likely to be greater with medical abortion than with surgical abortion, although the rates of hemorrhage remain low. Counseling regarding surgical and medical methods can address this increased risk of bleeding.(4)

Hysteroscopy is becoming one of the widest used gynecologic endoscopic methods. It can be found practically in every better equipped gynecologic department and in many outpatients' clinics since the office hysterectomy is raising trend in gynecologic endoscopy.

The analyzed case shows the possibility of diagnostics using hysteroscopy before the serious complications occur. Hysteroscopy is the method that enables taking bioptic samples with magnification from camera. The procedure is simple, painless, short, non-aggressive, which also reduces the risk of post-operative complications to a minimum. ${ }^{(5)}$

\section{REFERENCES:}

1. Kerns J, Steinauer. Management of post abortion hemorrhage, SFP Guideline \#201312013 Mar; 87(3): 331-42. doi: 10.1016/j.contraception.2012.10.024. Epub 2012 Dec 4.

2. Wisoff JH, Epstein F. Management of hydromyelia. Neurosurgery. 1989 Oct; 25(4): 562-71. 
3. Nele Gielen, Anja Krumeich, Remco C. Havermans, Feikje Smeets, Anita Jansen Why clinicians do not implement integrated treatment for comorbid substance use disorder and posttraumatic stress disorder: a qualitative study. Eur J Psychotraumatol. 2014; 5: 10,3402/ejpt.v5.22821.

4. Steven J Atlas, Richard A Deyo, Evaluating and Managing Acute Low Back Pain in the Primary Care Setting. J Gen Intern Med.Feb2001; 16(2): 120-131.

5. Sinisa Sijanovic1, Domagoj, Vidosavljevic2, Maja Kosuta-Petrovic3.Vaginoscopy and vaginal foreign body in children: case report. gineco.pulsmedia.ro/system/revista; 8(27): 40-42.

\section{AUTHORS:}

1. Ravindra Shelmohakar

2. Mithi Sooknundun

\section{PARTICULARS OF CONTRIBUTORS:}

1. Associate Professor, Department of Obstetrics and Gynaecology, Dr. D. Y. Patil Medical College, Pune.

2. Resident, Department of Obstetrics and Gynaecology, Dr. D. Y. Patil Medical College, Pune.

\section{NAME ADDRESS EMAIL ID OF THE CORRESPONDING AUTHOR:}

Dr. Mithi Sooknundun,

Mahindra Royale Society,

Windsor-2, b-102,

Pimpri, Pune-411018.

Email: mamzelle_2@hotmail.com

Date of Submission: 27/06/2014.

Date of Peer Review: 28/06/2014.

Date of Acceptance: 07/07/2014.

Date of Publishing: 10/07/2014. 